\title{
Correction to: Gadolinium: pharmacokinetics and toxicity in humans and laboratory animals following contrast agent administration
}

\author{
Julie Davies ${ }^{1}$ (D) $\cdot$ Petra Siebenhandl-Wolff ${ }^{1} \cdot$ Francois Tranquart $^{1} \cdot$ Paul Jones $^{1} \cdot$ Paul Evans $^{1}$
}

Published online: 28 February 2022

c) Springer-Verlag GmbH Germany, part of Springer Nature 2022

\section{Correction to: Archives of Toxicology (2022) 96:403-429 https://doi.org/10.1007/s00204-021-03189-8}

The article "Gadolinium: pharmacokinetics and toxicity in humans and laboratory animals following contrast agent administration", written by Julie Davies· Petra SiebenhandlWolf· Francois Tranquart. Paul Jones. Paul Evans, was originally published online without open access.

After Publication in volume 96, issue 2, page 403-429 the author decided to opt for Open Choice and to make the article an Open Access publication. Therefore, the copyright of the article has been changed to () The Author(s) 2021 and the article is forthwith distributed under a Creative Commons Attribution 4.0 International License, which permits use, sharing, adaptation, distribution and reproduction in any medium or format, as long as you give appropriate credit to the original author(s) and the source, provide a link to the Creative Commons licence, and indicate if changes were made. The images or other third party material in this article are included in the article's Creative Commons licence, unless indicated otherwise in a credit line to the material. If material is not included in the article's Creative Commons licence and your intended use is not permitted by statutory regulation or exceeds the permitted use, you will need to obtain permission directly from the copyright holder. To view a copy of this licence, visit https://creativecommons. org/licenses/by/4.0. The original article has been corrected.
Open Access This article is licensed under a Creative Commons Attribution 4.0 International License, which permits use, sharing, adaptation, distribution and reproduction in any medium or format, as long as you give appropriate credit to the original author(s) and the source, provide a link to the Creative Commons licence, and indicate if changes were made. The images or other third party material in this article are included in the article's Creative Commons licence, unless indicated otherwise in a credit line to the material. If material is not included in the article's Creative Commons licence and your intended use is not permitted by statutory regulation or exceeds the permitted use, you will need to obtain permission directly from the copyright holder. To view a copy of this licence, visit http://creativecommons. org/licenses/by/4.0/.

Publisher's Note Springer Nature remains neutral with regard to jurisdictional claims in published maps and institutional affiliations.

The original article can be found online at https://doi.org/10.1007/ s00204-021-03189-8.

Julie Davies

julie.davies@ge.com

1 GE Healthcare, Pollards Wood, Nightingales Lane,

Chalfont St. Giles, UK 